\title{
AFTER ACQUIRED RIGHTS, RESTRAINT ON ALIENATION AND PERPETUITIES PROBLEMS IN JOINT VENTURE AGREEMENTS*
}

\begin{abstract}
The typical joint venture agreement has a schedule attached to it describing the lands that are subject to the agreement. To prevent a party from obtaining an advantage in the acquisition of adjoining lands as a result of information obtained from the joint venture, the agreement often contains an after acquired rights clause. There are many reasons why a party to a joint venture agreement desires the right to determine who its partners will be, and to accomplish this, the joint venture agreement usually contains a clause restraining alienation of the property subject to the agreement. This article discusses the use of after acquired rights clauses and restraints on alienation in joint venture agreements and concludes with a consideration of the effect of the Rule against Perpetuities on the after acquired rights clause.
\end{abstract}

\section{A. AFTER ACQUIRED RIGHTS}

\section{Purpose}

A clause relating to after acquired rights is not standard in the sense that it is automatically a part of every joint operating agreement, but is nonetheless in common use. Its purpose is to prevent one joint operator from getting an advantage in the acquisition of rights to adjoining property as a result of the knowledge obtained by it from the joint venture, and also to prevent unseemly competition amongst the parties to the joint venture over the acquisition of such further rights.

It would appear from the reasons for its existence, that in a farmout agreement a farmor would probably favour such a clause and the farmee would probably seek to avoid it.

There seems little doubt but that the common law will provide a somewhat similar result without the application of a clause of this nature. This result has been brought about through the application of the laws pertaining to "constructive trusts" and "unjust enrichment". It is probable that these principles are applicable with or without the inclusion of a clause of the nature being considered.' This is not to say that such a clause is not necessary or advisable, but only that some of the same results will be obtained by application of common law principles.

One of the leading Canadian cases in this field is Midcon Oil \& Gas Limited v. New British Dominion Oil Company Limited and Brook." Despite the fact the defendant was found not to be liable in this instance, it was certainly made clear that the courts are not going to treat lightly the obligation of an owner of after acquired rights to deal fairly and openly with his joint operators.

- This paper was prepared through the combined efforts of B. V. Reed, John Stein and John Klebuc, all of MacPherson, Leslie and Tyerman, Regina, Saskatchewan; T. C. Wakeling, of McDougall, Ready, Wakeling, Youck and Mollard, Regina, Saskatchewan, and R. B. Laschuk, of Balfour, MacLeod, MeDonald, Moss, Laschuk and Kyle, Regina,

lliam. Fiduciary Relationships in Oil and Gas Venture, below, pp. 233-249. [1958] S.C.R. 314 (S.C.C.) 21 W.W.R. 229 (C.A.) 19 W.W.R. 317 (Alta.). For a discussion of this case, see Bredin, Types of Relationships Arising in Oil and Gas Agreements, (1964) 3 Alta. Law Rev. 333 at 340 and Burden, The Operating Agree-
ment-For the Development of Petroleum and Natural Gas Resources, (1963) 30 Sask. Bar Rev. 325 at 327. 


\section{Description of Area}

Perhaps the foremost concern in the drafting of an after acquired property clause is the land to be included in the definition of "new lands" to which the provisions of the clause shall relate. The area can be defined in several ways, but two of the available, and perhaps most common alternatives, are as follows:

(a) specifically designate the lands in terms of a stated parcel, or an area of land within a boundary drawn ' $x$ ' miles outside the perimeter of the initial lands.

(b) describe the "new lands" in terms of any lands in a document of title of which more than 50 per cent thereof is located within a specified area.

The second alternative is meant to cover the situation where, because of other interests located nearby, a party may be under obligation to share with more than one joint operator. The land in question is then involved only in the joint venture area in which it is principally located.

The restriction on after acquired rights may be determined not only by area, but also as to the type of interest. For instance, its application may be restricted to include only areas that may be acquired by Crown sales as distinct from freehold acquisitions.

\section{Term}

It is necessary to set a term on the application of the after acquired rights clause (at least recent opinion is to this effect) to avoid the rule against perpetuities. It is probable that some of the larger operators are also concerned to avoid the stigma of monopoly or restrictions on competition, and are therefore anxious to place a reasonable term on the application of the clause. This is also a prudent practice since the courts have always been anxious to prevent restraints on free trade over that period of time which can be reasonably justified by the circumstances under which it arises." The duration of the term is not standardized and appears to vary from 10 years to a period of one or two years.

\section{Acquisition by One Party}

The usual requirement is that if one party to the joint operating agreement obtains an interest in any portion of the "new lands" it shall thereupon provide the other party an opportunity to purchase an agreed interest therein at the same price or consideration as paid by the acquiring party. This is reasonably straightforward and workable except in the unusual case where the interest may be acquired for something other than a cash consideration, when difficulties as to valuation might well arise.

Where it is the intent of one party to acquire any interest in the "new lands", such a party must notify the other, and if the other is likewise interested, an attempt must be made to agree on a price to be bid. When a bid price is established the interested party makes the bid on behalf of both parties. If the interest in question is acquired, it is then deemed to be held for both parties under the terms of the operating agreement.

\footnotetext{
3 See Vancouver Malt and Sake Brewing Co. v. Vancouver Breweries Ltd. [1934| A.C. 181.
} 
In the event the parties are unable to agree on a bid price, each is free to make its own bid, and if successful, to hold the lands thus acquired to its own acount. To avoid the unfairness that can arise from one party not agreeing on a joint bid and subsequently bidding at a different figure than that indicated in the consultations, it is usual to provide that any change in the actual bid in excess of 5 per cent will give the other party a right to acquire a proportionate share of the land thus obtained by such altered bid. It appears to be generally conceded that a change of more than 5 per cent in such circumstances is a material change.

It is also possible that all parties to the joint operating agreement do not have equal access to information and are thereby deprived of an equal opportunity to assess the value of the "new lands". To guard against this, some clauses are designed to provide the party which was either not consulted, or had incomplete information, an option period of ten days from the date such full information was provided to acquire its share in the "new lands" acquired by one of the joint operators.

Further problems can arise over the possible need to select areas for which a lease or licence must be acquired. In such circumstances the areas the general kept in a non-lease or licence stage as long as possible and thereafter selected after consultation. If agreement is reached, obviously no problems arise, but otherwise it is necessary to resort to a special formula of alternate choices or selection by lot.

In the event of the necessity to drill a validating well on any "new lands" the possibility exists that all parties will not agree to participate. In such event, it is generally provided that only the parties who do participate shall be entitled to the benefit of the "new lands" which are thus validated, and that such new lands will be free of the operating agreement, but the participating parties shall enter into a new one in the same general form but without the non-participating entity as a party thereto.

There are undoubtedly many forms of an after acquired rights clause and the foregoing includes only the factors which have been taken into account in the common forms of agreement. There is not much law on the subject of after acquired rights clauses, and undoubtedly more variations will be devised as more problems come to light in the future, or as the present provisions come under more severe scrutiny through the ultimate test of judicial review.

\section{B. RESTRAINTS ON ALIENATION}

This portion of the paper will deal briefly with restraints on alienation and the legal effect of clauses which provide for restraints on alienation.

\section{Types of Alienation}

Generally speaking, contractual and property rights can be alienated in two ways, voluntarily and involuntarily. Voluntary alienation is most commonly effected by a transfer or assignment of all or a portion of a party's property or contractual rights. Voluntary alienation may also

\footnotetext{
4 See Appendix to this paper for an example of an after acquired rights clause.
} 
be effected by amalgamations, mergers and by a voluntary assignment in bankruptcy. Examples of involuntary alienation are seizure pursuant to writ of execution, lien or some judicial process, involuntary bankruptcy, foreclosure under a mortgage and in the case of an individual, death or insanity.

\section{Purpose of Restraints on Alienation}

Companies or persons who enter into a joint venture usually take considerable care in selecting their partners in the venture. The partners are often selected with specific objectives in mind, for example, financial resources, technical resources, management resources, political influence, marketing resources and any number of other objectives. A company or person might be quite happy to enter into a joint venture, or so to speak "get into bed" with X or Y, but they would be horrified at the prospect of entering into a joint venture with $\mathrm{Z}$. Other companies might be quite content to enter into a joint venture with any number of other companies or persons but would want to have some say in and control over who their partners will be. Accordingly, it is advisable when drafting a joint venture agreement to insert provisions containing restraints on alienation.

\section{Restraints against Voluntary Alienation}

Joint venture or joint operating agreements normally contain a provision which restricts the right of voluntary assignment either absolutely, or subjects the right of assignment to notices to and/or approval by all or a certain percentage of the other parties to the agreement.

It would appear that clauses of this type, when properly drawn, are enforceable even where they contain an absolute restriction on assignment." These clauses usually specifically exempt assignments made by a party to a parent or subsidiary corporation, or pursuant to a merger or amalgamation of such party with another corporation, or the sale of all or substantially all of the assets and undertakings of any such party to another corporation. They also often specifically exempt any assignment of all or a portion of the interest of a party by way of mortgage, pledge or charge upon such interest as security for a bona fide advance of monies to such party, provided that such an assignment is expressed to be subject to all of the terms and provisions of the agreement in question.

\section{Restraints against Involuntary Alienation}

Agreements of all kinds, including joint venture agreements, commonly contain provisions restricting voluntary alienation. They do not, however, commonly contain restrictions against involuntary alienation. An exception to this would appear to be the realty lease. If parties find it advantageous and desirable to provide restrictions against voluntary alienation, why ought they not find it equally advantageous and desirable to provide restrictions against involuntary alienation, for example, bankruptcy? Perhaps the explanation is found in the fact that it is

5 See McAvoy v. Royal Bank (1933) 3 W.W.R. 433. But see also McKillop and Benjafield v. Alexander (1912) 54 S.C.R. 551 and Gallagher v. Gallagher and Freeholders (1962) 40 W.W.R. 35. See also Di Castri, Canadian Law of Vendor and Purchaser 311-318 (1968). 
a very difficult, indeed, if not in some cases an impossible drafting job. However it is submitted that it is desirable to attempt to restrict the extent to which involuntary alienation can result and it is submitted that, generally speaking, such provisions would be enforceable provided, of course, that they do not run afoul of statutory provisions dealing with fraudulent preferences and similar matters.

It would not appear to take too much imagination to draft a clause which would effectively prevent alienation that would result from an involuntary bankruptcy. The clause would most likely provide for some pre-emption rights in favour of the other parties to the agreement upon the occurrence of a bankruptcy. Provided the clause came into existence at a time and under circumstances that would not offend the law respecting fraudulent preferences, we see no reason why the clause would not be legally effective and enforceable. Preventing alienation that would result from seizure under a writ of execution or other judicial process presents a far more difficult problem and unless one could come up with a triggering mechanism that would click before the writ of execution or legal process became effective, the prohibition against alienation that would result by seizure under a writ of execution or by judicial process would likely be ineffective.

Where individuals are involved agreements commonly contain a provision which gives the other parties to the agreement certain preemptive rights upon the death of the individual. It would appear advisable to include insanity of the individual in any such provision.

Involuntary alienation can also result from foreclosure effected pursuant to a mortgage, lien or charge and since the consequences of such a foreclosure to the other parties is as undesirable as any other type of alienation, it is submitted that one should consider inserting provisions which would prevent that type of alienation. However, as has already been indicated, clauses which prevent voluntary alienation normally exempt assignments by way of security. They need not, and in the appropriate case perhaps should not.

\section{THE EFFECT OF THE RULE AGAINST PERPETUITIES ON RESTRAINTS ON ALIENATION AND AFTER ACQUIRED RIGHTS}

The rules of law affecting perpetuities are based upon considerations of public policy; although the principle of private ownership requires that an owner of property shall have power to dispose of it as he thinks fit, yet public policy requires that the power should not be abused. Accordingly, the law from early times discouraged dispositions of property which either impose restrictions on future alienations of that property or fetter to an unreasonable extent the future devolution or enjoyment of that property.

\section{Restraint on Alienation Clauses}

It appears to be generally agreed that the typical clause imposing a restraint on alienation in the joint venture agreement is unaffected by the rule against perpetuities. The rule places a limit upon the powers of owners of property to designate who in the future shall enjoy the 
beneficial ownership. It does not seek directly to prevent restraints on alienation." It appears that restrictive covenants generally do not come within the ambit of the perpetuity rule and an objection on this ground cannot be taken successfully where the covenant is created in praesenti.'

\section{After Acquired Rights Clauses}

The rule against perpetuities has been stated as follows; "an interest in land is void $a b$ initio unless it must necessarily vest, if at all, not later than 21 years after some life in being at the creation of the interest." The effect of the usual after acquired lands clause in the joint venture agreement might be summed up as follows; the parties agree that if at some future time during the term of the agreement any party acquires an interest in oil and gas rights as to specified lands or lands falling within a prescribed area, such party will notify the other parties who will then have a specified period within which to elect to acquire their proportionate shares thereof upon payment of their share of the acquisition costs. Does the rule against perpetuities have any application to the after acquired provisions of the joint venture agreement? Before attempting to consider this question, it might be useful to state some of the general principles with respect to the rule against perpetuities that the courts have developed over the years.

Prior to the decision of the Supreme Court of Canada in Harris v. Minister of National Revenue," it was thought that there were three possible alternatives with respect to a contract which created a right of property to arise in futuro. Firstly, the contract was a personal contract only; secondly, the contract created a limitation of land only; and thirdly, the contract created both a limitation of land and a personal contract; and the accepted statement of the law was as follows:

A contract relating to a right of or equitable interest in property in futuro may be intended to create a limitation of land only, in which case, if the limitation is to take effect beyond the perpetuity period, the contract is wholly void and unenforceable; or the contract may, upon its true construction, be a personal contract only, in which case the rule does not apply to it; or it may, upon its true construction, be, as regards the original covenantor, both a personal contract and a contract attempting to create a remote limitation. In the last-mentioned case the limitation will be bad for perpetunity, but the personal contract will be enforceable, if the case otherwise admits, against the promisor by specific performance or by damages, or against his personal representatives in damages, or possibly by specific performance. Unless, however, the burden of the contract runs with the land, it will not be enforceable against an assign of the promisor. In all cases it is a question of construction whether the contract is intended to create a limitation of property only, or a personal obligation only or both. ${ }^{10}$

In the Harris case the right to exercise the option did not arise until the expiration of 200 years from the date of the lease. The court held that the option offended the rule against perpetuities and was void, and as a result, the lease took effect as if the void limitation created by the option were omitted. The appellant argued that even if the clause granting the option, in so far as it created a limitation of land, was bad for perpetuity, it also evidenced a personal contract which was unaffected by the rule against perpetuities and could be enforced by the lessee

6 See Blackburn v. McCallum (1903) 33 S.C.R. 65.

T See McKenzie v. Childers (1890) 43 L.R. Ch. D. 265

: Di Castri. Canadian Law of Vendor and Purchaser 124 (1968).

1029 Halsbury's Laws 297-8 (3d ed.). 
or his personal representatives against the lessor so long as the lessor had not disposed of the property."

Mr. Justice Cartwright reviewed the decisions which had been relied on to support the proposition that a contract could create both an interest in land and a personal obligation and concluded as follows:

It appears that Farwell, L.J., in the passage quoted, was considering two types of contract, one "merely personal" and the other "creating an interest in land". The meaning of the phrase "an agreement merely personal" as he used it is simply an agreement which does not create an interest in land. So understood the only objection to accepting what he has said appears to me to be the difficulty of suggesting a single contract which could be at once "merely personal" and one creating an interest in land.

Be that as it may, I am satisfied that as a matter of construction the clause granting the option to the appellant which we are considering in the case at bar is one agreeing to create a contingent future interest in the land demised and nothing else and that it is void as infringing the rule against perpetuities. If the agreement to create the contingent future interest is taken out of the clause there is no agreement left to be described as a personal contract.1"

It is true that the Harris case was decided on a construction of the clause as one creating an interest in land and nothing else, but it is respectfully submitted that if the third category of contract listed above still exists after this decision, it is going to take a very clever draftsman to create a contract which is "at once 'merely personal' and one creating an interest in land." 13

Essentially, the after acquired clause appears to grant mutual options for the benefit of the parties to the contract and their assigns. However wide the rights may be, it is usually possible to say that a particular parcel of land is or is not subject to the clause. Accordingly, if the agreement is silent as to time and makes no mention of lives in being, the effectiveness of the clause (except to the extent that it may be regarded as a purely personal contract) becomes strongly suspect as an attempt to create an interest which could remain unvested beyond the perpetuity period.

If one regards the after acquired clause as the granting of mutual options (which create equitable interests in land)," such options appear to offend the perpetuities rule and, therefore, are void if unlimited in point of time. ${ }^{1 i}$ However, an option which is for a term certain but which may be exercised sooner upon the happening of a certain event does not apparently offend the rule. If the optionor has the right to terminate the option, or at least do acts which might cause its termination, the perpetuities rule does not apply because the life of the optionor is treated as the life in being. ${ }^{1 !}$

\section{Avoiding the Rule Against Perpetuities: Points for Discussion}

Conceding the application of the perpetuities rule to a normal construction of the after acquired clause, and conceding the need of the parties to create binding provisions of this kind whose terms may exceed the permitted period, what alternatives, if any, are available to the draftsman of the joint venture agreement? The following suggestions are made to elicit discussion on this question.

11 (1966) 57 D.L.R. 403 at 410.

12 Id. at 416.

13 Id.

1. See United Fuel Supply Co. v. Volcanic Oil and Gas Co. (1911) 3 O.W.N. 93 and

Frobisher Limited v. Canadian Pipelines \& Petroleums Limited [1960| S.C.R. 126.

1.: See Yates Investment Company v. Willoughby (1964) 46 W.W.R. 499.

Ii See Pan American Petroleum Corporation v. Potapchuk (1964) 46 W.W.R. 237. 
(i) Creation of Personal Obligation Only

As the rule has no apparent application to contracts which are personal in nature only, the agreement could provide that the after acquired clause shall operate only as a personal covenant, and further stipulate that no assignment of the agreement shall be binding in the absence of a novation which passes the personal covenant to the successor in interest. The obvious limitation here is that a disposition in breach of the contract may give rise to an action for damages but rights over the land itself may be lost. For the practical considerations of the oil industry, this does not seem to be an attractive alternative.

\section{(ii) Subjecting Existing Interests to an Encumbrance or to}

\section{Liquidated Damages.}

The disadvantage of the above suggestion lies mainly in the possibility of a loss of rights over the land to which the clause applies with damages as the only possible alternative remedy. While the cure about to be suggested may well constitute a worse fate than the ailment itself, it is necessary to advance it due to a dearth of available sanctions which can be marshalled before the perpetuities-sensitive draftsman. The contract as above mentioned would be expressed to be purely personal as to the after acquired clause and make the further stipulation as to novation, but it would be coupled with a built-in sanction designed to eliminate or at least discourage breaches of the covenant. The sanction is to have the parties grant to each other a lien or charge on their existing interests.

Since the charge on land would vest immediately in each party, the term of the lien could be perpetual and no apparent breach of the perpetuities rule results. The lien or charge could specify the amount of liquidated damages consequent upon a breach of the personal covenant or provision could be made for the forfeiture of the interest of any party who fails to secure a novation on the part of a successor in interest. This alternative also has limitations in the long range view of things. The properties subjected to the lien will in time be depleted and rendered valueless and any attempt to subject other lands to the charge is again caught by the application of the perpetuities rule.

The above suggestion may be entirely impractical, but in the absence of statutory intervention the choices are limited. On the other hand, is the application of the rule that unpalatable?': Perhaps we should not be attempting to tie parties to each other for extensive periods with contracts that one hundred years from now may well be as archaic as the quill pen. The solution will be found in balancing certainty for the foreseeable future with unpredictability beyond.

17 Many joint venture agreements contain the following provision with respect to the Rule against Perpetuities, namely:

"Perpetuities: Notwithstanding anything herein elsewhere contained any right hereunder
of a party to acquire any interest hereunder from the other party shall not extend of a party to acquire any interest hereunder from the other party shall not extend
for a longer period than the lifetime of the lawful decendants now living of Her Majesty Queen Elizabeth and twenty-one (21) years thereafter." 


\section{APPENDIX \\ After Acquired Lands Clause}

(a) In this Clause the expression "new lands" means:

[Select one of the following three alternatives:]

(i) specifically designated lands, or

(ii) any lands comprised in a document of title more than Fifty $(50 \%$ ) percent of the area of which falls within the heavy outline shown on Schedule " ...", or

(iii) any lands comprised in a document of title more than Fifty $(50 \%)$ percent of the area of which falls within that area comprised within a line drawn ......... miles around the outside perimeter of the lands as defined in Clause 1 of this Agreement.

(b) The provisions of this Clause relating to the acquisition of new lands shall be in effect for the period commencing as of the date of this Agreement and expiring of this Agreement, whichever first occurs.

or on the date of termination

(c) During the period set out in subclause (b) aforesaid, if any new lands become available for acquisition and if one of the parties desires to consult for the purpose of submitting a bid therefore, then the parties shall consult and attempt to reach a price to be bid for such new lands and if agreement can be reached Farmee shall submit the bid on behalf of the parties and if acquired, such new lands shall be owned by the parties in accordance with their participating interests as set forth in the Operating Agreement and shall be subject to the provisions of the said Operating Agreement and to the applicable provisions of this Clause.

(d) If, after consultation in the manner provided in subclause (c) above, the parties are unable to agree on a price to be bid for new lands, each shall be free to bid for its sole account and if acquired, the new lands shall be owned by such party free and clear of any obligation to the others unless the new lands were acquired by such party for a price which differed by more than Five $(5 \%)$ percent from the price such party represented it was prepared to agree for acquisition. In the event of this greater than five $(5 ; i)$ percent differentiation, the acquiring party shall notify the other parties and the others shall have the right for a period of Ten (10) days from receipt of such notification to acquire their respective proportionate interests (as set out in the Operating Agreement) in such new lands by paying to the acquiring party within the said Ten (10) day period, their proportionate shares of the acquisition costs. If all parties so elect the new lands shall then be owned by the parties in accordance with their participating interests as set forth in the Operating Agreement and shall be subject to the provisions of such Agreement and to the applicable provisions of this Clause. If less than all parties so elect, then those electing shall enter into an Agreement in the form of the Operating Agreement with the initial acquiring party retaining the interests of those parties not so electing.

(e) If the parties do not consult prior to acquisition or if any well is being drilled pursuant to this Agreement or the Operating Agreement 
which well may reasonably be expected to evaluate new lands and if any party has not received all information with respect to such well to which such party is entitled in accordance with the provisions of this Agreement or the Operating Agreement then, if any party bids for such new lands and acquires them, such acquiring party shall forthwith give written notice to the others and the other parties shall have the right for a period expiring Ten (10) days from receipt of the last of all such information, in the case of such a well being drilled, or for a period of Ten (10) days from receipt of notification of such acquisition in the event of non-consultation where no well is involved, to acquire their proportionate interests and in this respect the pertinent provisions of subclause (d) above shall apply.

(f) Rentals and taxes attributable to new lands owned and held by the parties in accordance with their respective participating interests as set forth in the Operating Agreement shall be initially advanced and paid by ................ and the other parties shall reimburse

for their proportionate shares of such payments upon being billed therefor.

(g) If any new lands are owned by the parties in accordance with their participating interests and which lands are in a form from which Petroleum and Natural Gas Leases or Licences may be selected, then the parties agree that such new lands shall remain in the non-Lease or non-Licence stage for as long a period as is possible having regard to the pertinent laws, rules and regulations. At least Thirty (30) days prior to the date upon which such Leases or Licences must be selected, the parties shall consult and attempt to agree upon a Lease and/or Licence selection. If the parties can agree, Leases and/or Licences shall be selected and those selected shall form the particular Lease or Licence selection of the parties. If the parties cannot agree then Leases or Licences upon which agreement can be reached shall be selected and the balance up to the maximum permitted in each case shall then be selected with each party alternately designating quarter sections up to the maximum permitted with the party having the largest undivided interest commencing such designation and with the number of quarter sections designated by each party on each round being directly proportionate to each party's undivided interest based on the party with the smallest interest being entitled to designate one quarter section. If the interests are equal the order of designation shall be decided by lot. Leases and/or Licences so selected and designated shall form the selection of the parties and shall be owned and held by the parties in accordance with their participating interests and shall be subject to the Operating Agreement and to the applicable provisions of this Clause.

(h) If any new lands are acquired by the parties in accordance with their respective participating interests from which Leases and/or $\mathrm{Li}$ cences may be selected and if before such selection it is necessary to drill what is commonly termed a validating well on any portions of such new lands, then, if the parties cannot agree on such drilling, any party or those agreeing may proceed to drill such well for its sole account. In this event any party not drilling shall convey to the parties drilling, upon completion, capping or abandonment of such well at 
the depth prescribed to give a right of selection, the entire interest of the parties not participating in such drilling, in those portions of the new lands to which such validating well pertains. Such new lands shall then cease to be subject to the Operating Agreement and the parties acquiring the new interests shall enter into an Agreement for future operations thereon in the form of the Operating Agreement. It is understood and agreed that the type of well contemplated by this subclause is not the type contemplated by the independent drilling Clause of the Operating Agreement.

(i) All new lands owned and held by the parties in accordance with their respective participating interests shall be owned and held by them as tenants in common. 